\title{
Zoonotic Abortion in Herds: Etiology, Prevention and Control
}

\author{
Kelvinson F. Viana ${ }^{1}$ and Marcos S. Zanini ${ }^{2}$ \\ ${ }^{1}$ Federal University of Ouro Preto \\ ${ }^{2}$ Federal University of Espírito Santo \\ Brazil
}

\section{Introduction}

In recent years, an increasing number of zoonotic diseases and outbreaks affecting people around the world and it is estimated that of the emerging infectious diseases of humans, $75 \%$ are zoonosis (Merianos, 2007). Clearly, these recent events, a number of issues are involved, a fundamental question to be the livestock production systems, as well as the mismanagement of the health of livestock. In this context it is worth questioning the influence of agruculture genetics of microorganisms and the impact that may result from public health (Rosenthal, 2009). A program of activity in animal health planning is applied regularly veterinary herd management and to maintain good animal health and productivity at optimum levels.

Zoonosis affecting reproductive system animals and potentially humans, are common in herds worldwide, requiring prevent them correctly (Del Fava et al., 2003). This involves education, health and performance of vaccine efficacy in herds. However, although this practice capable of generating results broadly favorable, due to increased herd immunity and reduce the impact of an outbreak, vaccination alone is not able to prevent zoonotic infections and loss (Sanderson \& Gnade, 2002). Herds infected with zoonotic agents such as Brucella abortus, Campylobacter spp., Coxiella burnetii, Toxoplasma gondii, among others, are deeply affected both the economic point of view, due to losses in production rates as a whole, they become capable disease transmit to humans. In this context, the susceptibility to infections, mainly farmers and others rural workers who daily with the animals carry zoonosis (Viana \& Zanini, 2009b).

This problem is more complex developing countries compared with developed countries, due to a several factors such as lack of intensive programs for control and eradication certain diseases. What is more aggravating the epidemiological situation neglected diseases is underreporting, especially in Latin America, Africa and Asia. Therefore, this chapter provides an approach of some zoonotic agents that cause abortions, as well as attention of farmers in the prophylaxis and control these microorganisms, in view of risks and implications to human health. 


\section{Brucellosis}

Brucellosis is one of the most important worldwide zoonotic diseases affecting livestock and humans (Corbel, 1997). According to Gorvel \& Moreno (2002), although the classical definition of Brucella species describe these bacteria as facultative intracellular parasites, this definition does not honor their true nature which is better understood as a facultative extracellular intracellular parasite. That means that the Brucella preferred niche is the intracellular environment of host cells. This environment sustains extensive replication, allowing bacterial expansion and the subsequent transmission to new host cells, frequently achieved through the heavily infected aborted foetus.

Brucella infection is responsible for the decrease from 20 to $25 \%$ in milk production, 10 to $15 \%$ in meat production, $15 \%$ loss of calves due to abortions, increased $30 \%$ in the rate of replacement animals, increased calving interval of 11.5 to 20 months. In addition, every five infected cows abort, one or become permanently infertile (Acha \& Szyfres, 2003). Besides the loss of animal productivity, brucellosis is a zoonosis of major importance in health public (Freitas \& Oliveira, 2005). The species that may infect man are B. melitensis, B. suis, B. abortus, and $B$. canis. B. melitensis colonizes ovine stock and is the frequent cause of brucellosis, globally in humans.

\subsection{Important aspects in public health veterinary}

The transmission of Brucella infection and its prevalence in a region depends upon several factors like food habits, methods of processing milk and milk products, social customs, climatic conditions, socioeconomic status, husbandry practices and environment hygiene. In this context, environmental sanitation is particularly important (Mantur \& Amarnath, 2008).

Despite the ongoing demonstrations and disclosures about risk from the consumption of raw inadequately treated by heat, contact with animals without observing safety precautions, handling and manipulations viscera, and by products excretions of animals without the use of equipment individual protection, brucellosis remains an important public health problem world (Freitas et al., 2001). Information relating to the activities of livestock management is fundamental to the generation of animal products high quality. However, often not enough information to small producers, cowboys and others working in rural areas and this lack of information is still an obstacle on the health of livestock (Viana et al., 2009a,b).

Brucellosis in pregnancy has no effect on the incidence of congenital malformations or stillbirths. Preterm delivery and low birth weight can be seen as pregnancy outcomes in brucellosis (Gulsun et al., 2011). It as been shown a remarkably high incidence (43\%) of first and second-trimester spontaneous abortions among pregnant women with active brucellosis and the intrauterine fetal death rate in the third trimester was 2\% (Khan et al., 2001). Rifampicin is considered the drug of choice for treatment pregnant women because its safety and can be used with or without combination with other antibiotics such as cotrimoxaxole and cephtriaxone (Gulsun et al., 2011; Karcaaltincaba et al., 2010; Pappas et al., 2005; Solera, 2000).

\subsubsection{Failures in programs of control and eradication brucellosis}

Control and eradication of brucellosis is a measure desired by many countries here the disease is endemic. However, this result is difficult and expensive, taking into account the 
specific climatic, geographical, socio-economic, technical resources and personnel, prevalence of disease, as well as the strict commitment of farmers in vaccinations programs (Kolar, 1984). In this sense, developing countries have encountered major difficulties both in setting and in achieving success in their programs of control and eradication of animal brucellosis (Blasco \& Moryon, 2010; Hegazy et al., 2009; Nateloski et al., 2010). Certainly, some significant flaws can be identified, such as voluntary vaccination and lack of conditions of programs financially afford to economic losses of farmers, the loss of positive animals (Hegazy et al., 2011; Nateloski et al., 2010). Furthermore, cultural issues should also be taken into account, since in India, culling of infected cows is a taboo, affecting effort to eradication disease (Gwida et al., 2010).

The fact that brucellosis be spread herds in several regions has caused concern from the standpoint of public health, especially when it comes to developing countries. The issue is more sensitive in rural areas, where habits of people in eating unpasteurized milk, as well as frequent contact with animal secretions and remains of the placenta (Figure 1) and aborted fetuses are, without doubt, most important risk factors to health human (Almuneef et al., 2004; Makita et al., 2010; Vasconcellos, 3003; Viana et al., 2009). Moreover, risk practices in rural areas such as skinning of stillborn lambs and kids, as well as crushing the umbilical cord of newborn lambs and kids with teeth can also be contributing factors (Hussein et al., 2005). However, situations such as the habit of eating aborted fetuses by populations in Equedor, can be characterized as a risk factors (Mantur \& Amarnath, 2008).

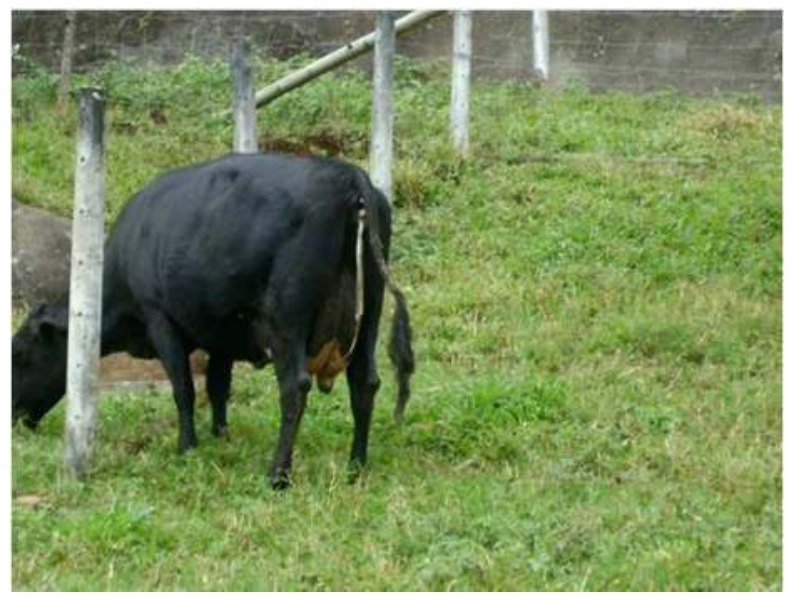

Fig. 1. Cow placenta exposed in the pasture. Situations as shown in this figure are common, characterized as a risk factor for infection by Brucella abortus in farmers who deal daily with livestock.

Brucellosis prevalence varies very widely in equine $(0.24-37.50 \%)$, bovine $(0.58-35.90 \%)$, caprine $(0.40-33.3 \%)$, ovine $(0.28-16.70 \%)$ and camelidae $(1.8-7.48 \%)$, while humans had the least prevalence $(0.89-4.10 \%)$ (Gul \& Khan, 2007). However, the true incidence of human brucellosis in most countries is still unknown. Really is found in Latin America, Africa, Asia, Middle Eastern and Southern European, certainly due to underreporting (Lucero et al., 2008; Mantur \& Amarnath, 2008). In the context, african countries deserve greater attention in the 
epidemiological scenario, since networks and programmes of surveillance, notification and vaccination are virtually nonexistent. Furthermore, the majority countries are extremely limited economic, in addition, to the habits os people living with their livestock. Besides this, a most aggravating factor is that there is much more morbid endemic infectious diseases such as malaria. Patients presenting with febrile frames are empirically diagnosed with malaria, and only the non-responders are tested for brucellosis (Pappas et al., 2006).

Prevention human brucellosis depends mainly on the control or eradication of the disease in animals. However, few countries were successful in eradication it from their herds, such as Australia, Canada, Denmark, Finland, Netherlands, New Zeland, Norway, Sweden, UK and Japan. Stocks successful these countries are an exemple to those who seek better results in their eradications programs. However, control of infected animals in developing countries requires considerable affort to build solid infrastructure that educates people about the risks of contracting brucellosis (Seleem et al., 2010). Although rural populations, as well as professionals who deal directly with cattle industry are at higher risk situations, it is important to note that urban populations in developing regions are also at risk of acquiring the disease through comsumption products of animal origin in bad (Franco et al., 2007). In the general context, with no interest and mutual effort of all aspects of society, with measures of health education and, above all, political support, the changes success in the eradication brucellosis is almost nonexistent.

\section{Campylobacteriosis}

Campylobacteriosis it is a zoonotic disease caused by several species of the genus Campylobacter. Thermophilic species are important targets of research in veterinary public health due to environmental persistence and a large number of potential hosts (Hannon et al., 2009). Campylobacter jejuni (C. jejuni) is the leading cause of bacterial gastroenteritis caused food in the world, and interest in this species has increased in recent years as a result of growing appreciation of its importance as a pathogen and the availability of new model systems and technologies genetic and genomic (Young et al., 2007), followed by Campylobacter coli (C. coli) (Tam et al., 2003).

Often, it is reported that the contamination of poultry meat and eggs is the main cause of infection in man (Friedman et al., 2004). However, it has been reported that the consumption of raw fruits and vegetables is an important risk factor for Campylobacter infections, especially for vegetables sold packaged (Verhoeff-Bakken et al., 2011). In addition, water contamination, ingestion of unpasteurized milk and contact with farm animals presenting diarrhea has been associated with outbreaks campylobacteriosis (Butzler et al., 2004; Gilpin et al., 2008; Huang et al., 2009; Pebody et al., 1997).

Infection with $C$. jejuni causes symptoms of diarrhea characterized by often bloody abdominal pain, fever and headache, and the incubation period of 1-10 days. However, not only the infection itself is worrying, but also its consequences, such as Guillain-Barré syndrome, characterized by a subacute polyneuropathy. This syndrome is very severe, mortality rate may reach $2-3 \%$ and major neurological sequelae in $20 \%$ of cases (Hughes \& Rees, 1997; Leonard et al., 2004; Moore et al., 2005). However, patients with C. jejuni-related Guillain-Barré syndrome can show transient slowing of nerve conduction, mimicking demyelination, but $C$. jejuni infection does not appear to elicit acute inflammatory demyelinating polyneuropathy (Kuwabara et al., 2004). 


\subsection{Bovine genital campylobacteriosis}

Bovine genital campylobacteriosis (BGC) also known as bovine venereal campylobacteriosis (BVC) is transmitted mainly by Campylobacter fetus subsp. veneralis and Campylobacter fetus subsp. fetus. The two species cause reproductive problems in cattle; however, the manifestation infection with this subspecies differs in the occurrence and pathogenesis. However, infection with C. fetus subsp. fetus is more related to sporadic abortions in cattle, and enzootic infertility in sheep (Stynen et al., 2003). BGC is closely associated with reduced pregnancy rates, low fertility, embryo mortality, abortions and increased calving interval (Mshelia et al., 2010). In males the infection is limited to the preputial cavity, but no clinical abnormalities were absorved in infected animals. However, these animals become asymptomatic carriers and are very important in the transmission of bacteria during intercourse. There may be a decrease in libido for excess service due to high repetition rates of estrus (Jesus, 1999).

The BGC is a difficult disease to control in countries with large cattle herds, were the dominant management system uses natural breeding. Because it is a sexually transmitted disease, initial clinical signs are not always apparent and when the disease is found in the herd, economic losses are already large (Alves et al., 2011).

BGC presents with worldwide distribution, paying attention to countries that the clinical disease has been recently confirmed as Argentina, Australia, Austria, Brasil, Costa Rica, France, Ireland, Jamaica, Namibia, New Zeland, South Africa, United Kingdom, United States and Uruguay (OIE, 2011) (Figure 2). However, understanding the epidemiology BGC not easy to official agencies, since many countries fail to report the incidence and outbreaks of disease. This is clearly visible in the records of the OIE (Fig. 2), mainly in African and Asian countries.

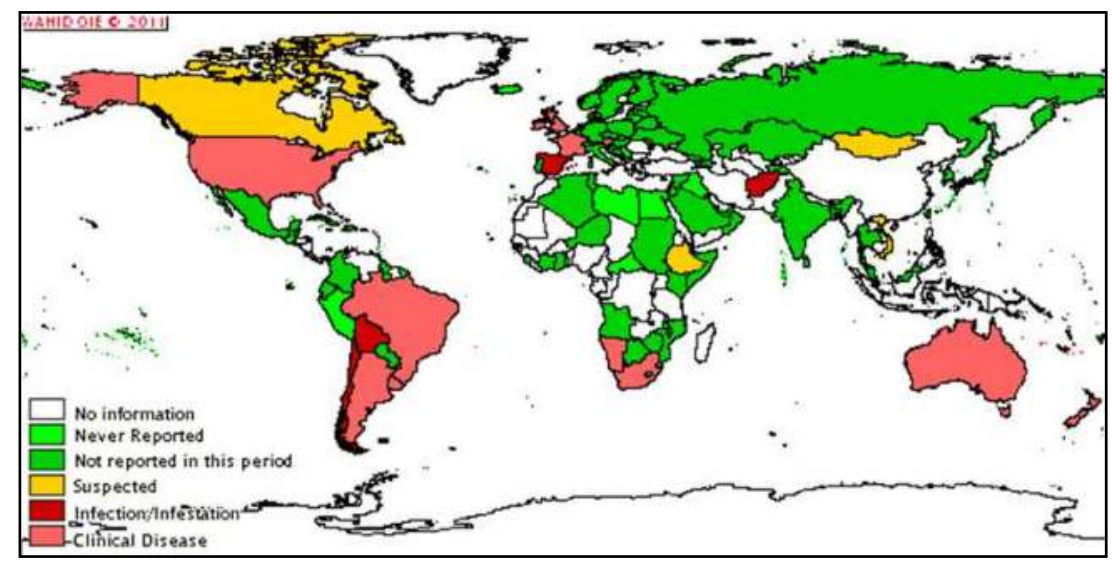

Fig. 2. Global distribution bovine genital campylobacteriosis from July to December 2010. Adapted from OIE (2011)

The establishment control program BGC requires artificial insemination with semen exempt from microorganism (BonDurant, 2005). This factor is paramount to be successful in the program. However, when involved large herds of cattle, where extensive creation system is 
predominant, and the high cost of litigation, technological difficulties, and properties of human resources, success can be compromised (Alves et al., 2011). Furthermore, detection and identification of the agent are key-factor in control programs, being established in the handbook of the World Organization for Animal Health (OIE) Manual of Diagnostic Tests and Vaccines for Terrestrial Animals. However, a major study showed that, overall, a variety of methods for detection and identification $C$. fetus subsp. veneralis are in use, these was a lack of harmonization that may have consequences for the description of the health status of countries and may lead to disputes with respect to trade regulations (Van Bergen et al., 2005).

BGC vaccination in herds, despite being a best practice, has not been widely practiced, although it has been quite effective in the prevention of repeated abortions and turnover (BonDurand, 2005). Certainly, the lack of information by farmers is still an obstacle for this practice preventive BGC established in herds. Partly, too, commercial vaccines have not been efficient enough to avoid negative impact of natural infection (Cobo et al., 2003). Furthermore, route vaccine administration can also be correlated with successful prevention, since the vaginal route, compared with subcutaneous route has shown better results compared to commercial vaccines (Cobo et al., 2004) due to generation IgA antibodies are responsible for mucosal immunity. Nevertheless, cost-benefit control of BGC by vaccination is positive because has been shown that return is around 18 times the amount invested in vaccination, and the gain of only a weaned calf equivalent about cost vaccination of 100 animals (Leite, 1977).

\section{4. $Q$ fever}

$\mathrm{Q}$ fever is a zoonosis of worldwide distribution caused gram-negative intracellular bacteria Coxiella burnetii, which can infect arthropods, birds and animals (Cutler et al., 2007). In humans, infection is usually asymptomatic, however, can progress to acute or chronic, with flu-like illness, pneumonia, hepatitis or endocarditis, spontaneous abortion and stillbirths respectively (Arrycau-Bouvery \& Rodolakis, 2005). The infection mainly occurs after direct or indirect contact with infected animals, principally mammals, usually as a result of inhalation of contaminated aerosols from amniotic fluid or placenta. Currently it is not possible to accurately estimate the true prevalence infection in domestic ruminants, due to lack of well designed studies. However, there has been detection C. burnetii in all five continents (except in New Zealand being only country with a reported apparent prevalence of zero), with a wide range, in whatever kind. The apparent prevalence is slightly higher in cattle $(20.0 \%$ and $37.7 \%)$ than in small ruminants sheep and goats (around $15 \%$ to $25 \%$ ) (Guatteo et al., 2011).

\subsection{Reproductive disorders in farm animals}

Infections by C. burnetii in animal production are mostly asymptomatic, however, may be related reproductive disorders such as abortion, stillbirths, repetition heat, low birth weight animals and metritis. Nevertheless, latter clinical manifestation appears to be unique in cattle (To et al., 1998), occurring during first three weeks after birth, with fetid vaginal discharge and/or increase in body temperature (Sheldon et al., 2006). However, in dutch dairy herds, as been shown infection with C. Burnetii is not a major cause of metritis, although apparently microorganism has been circulated in animals (Muskens et al., 2011). 
In most cases, abortion occurs late pregnancy; with free that can range from 3 to $80 \%$ (Angelakis \& Raoult, 2010) with unspecified characteristic clinical signs infection with C. burnetii. Aborted fetuses appear normal but infected placentas exhibit intercotyledonary fibrous thickening and discolored exudates, which are not specific to $Q$ fever (ArrycauBouvery \& Rodolakis, 2005). C. burnetii can also be recovered from milk for up to 32 months. Goat shed C. burnetii in feces before and after kidding and the mean duration of excretion is 20 days (Angelakis \& Raoult, 2010). Furthermore, there may be shedding bacteria in the urine, semen and vaginal discharge mucus. An important factor related to abortion rates in herds is the temperature, since fewer abortions lake place between months November and December. However, this occurrence increases gradually from January to February, decreasing again in March (Cantas et al., 2011).

A relevant issue is infestation of cattle by ticks during months when temperature is higher. Previous studies have shown that ticks seem to play an important role in the dissemination of bacteria in animals, especially wild, believing it to be an important factor in the transmission to domestic animals (Marrie et al., 1986; Psaroulaki et al., 2006). On the other hand, a recent study developed in the Netherlands, after three years of an outbreak $Q$ fever, researchers investigated the role ticks in the transmission C. burnetii, showing that actual risk of this infection by ticks is negligible. Moreover, for future risk assessments, it might be relevant to sample more ticks in the vicinity of previously C. burnetii infected goat farms and to assess whether C. burnetii can be transmitted transovarially and transstadially in I. ricinus ticks (Sprong et al., 2011).

\subsection{The zoonosis}

Certainly, the main rout transmission of C. burnetii to humans is through inhalation of contaminated aerosols from placenta, amniotic fluid, wool, clothing contaminated with faces, manure, or transhumance herds infected through a valley (Arrycau-Bouvery \& Rodolakis, 2005). In addition, person to person transmission is possible and coughing is associated with some proportion of $\mathrm{Q}$ fever cases and emits many particles of respiratory fluid that quickly attain diameters less than $100 \mu \mathrm{m}$; these particles can be inspired and, depending on particle aerodynamic diameter, deposit in the alveolar region or upper respiratory tract (Jones et al., 2006). Nevertheless, infected ruminants can shed C. burnetii during lactation period, transmission can occur by consumption raw milk (Maurin \& Raoult, 1999). This form transmission can be aggravated by increasing the number of farms targeted for rural tourism (Chang et al., 2010).

There are no specific clinical sings for infection by C. burnetii in the acute phase, with variation in symptom severity from patient to patient. However, there is often a prolonged fever, usually accompanied by severe headache, pneumonia, which in most cases are clinically asymptomatic or mild, hepatitis, can be found three ways: an infectious hepatitislike form of hepatitis with hepatomegaly but seldom with jaundice, clinically asymptomatic hepatitis, and prolonged fever of unknown origin with characteristic granulomas on liver biopsy; pericarditis, skin rash, neurological signs such as meningoencephalitis, lymphocytic meningitis and peripheral neuropathy. The clinical care of the chronic phase is mainly characterized by endocarditis, occurring in predisposed patients with vascular changes and the heart valves (Angelakis \& Raoult, 2010). 
In pregnancy, there is risk of mortality for both the mother and fetus as result of $Q$ fever other serious complications include spontaneous abortion, oligoamnios, stillbirth, and premature delivery. Obstetric complications occur significantly more often as C. burnetii infects the patient at an early stage of her pregnancy (Carcopino et al., 2009). Although traditional treatment is with doxycycline, other drugs has also been used in pregnant women, such as azithromycin (Cerar et al., 2009) and cotrimoxazole, allowing the birth healthy babies (Carcopino et al., 2009).

Studies have shown that professional veterinarians and other workers who deal directly with farm animals in slaughterhouses, dairy industry and laboratory workers are at greater risk of infection by C. burnetii (Chang et al., 2010; Monno et al., 2009). Moreover, on can speculate that humans can act as reservoirs of the microorganism due to occurrence of spontaneous excretion of C. burnetii in faces and milk (Mediannikov et al., 2010). Another relevant issue is the presence bacteria in chicken eggs and mayonnaise, with strong possibility of this zoonotic agent these products to be feasible (Tatsumi et al., 2006). Thus, risk factors for infection can transcend rural people, wounded in urban areas and consequently generate more grievances in public health.

It is essential that certain preventive measures are taken to prevent spread infection by $C$. burnetii. Shares health education farmers to avoid environmental contamination, tick control, handling of placental membranes, fetal fluids and aborted fetus. Only seronegative animals and/or be included vaccinated herds. Furthermore, in herds were infection installed, cows must give birth in isolated locations that should be disinfected as well as the tools used in childbirth. Laboratories should provide necessary information and secure facilities to its employees (Angelakis \& Raoult, 2010; Arrycau-Bouvery \& Rodolakis, 2005).

\section{Toxoplasmosis}

Toxoplasmosis is a cosmopolitan disease caused by obligate intracellular protozoan Toxoplasma gondii. Certainly one of the most successful parasite in the world and can infect all warm-blooted animals, characterized as an important zoonotic agent (Dubey et al., 2009; Innes et al., 2009). Domestic and wild cat are the only definitive hosts of the parasite. After ingestion of tissue cysts, parasites invade enterocytes; undergo cycles of division and differentiation in microgametocytes and macrogametocytes merging to form an oocyst. This is shed in faces in the environment (Ajioka et al., 2001). Intermediate hosts to be infected with oocysts, two phases allow multiplication of the parasite. The first, rapidly multiplying, stage of the parasite is known as tachyzoite. After 1 to 3 weeks tachyzoites transform into bradyzoites: the slowly replicating form that is contained in tissue cysts (Dubey et al., 1998).

In humans, there is correlation between alterations nervous and infection $T$. gondii, such as car accidents, personality changes and schizophrenia. In addition, it has been suggested to have positive relationship between toxoplasmosis and the etiology of suicide attempt (Yagmur et al., 2010), especially in women of postmenopausal age (Ling et al., 2011). Nevertheless, further researches in this area are needed to confirm this association complex.

\subsection{Infection in farm animals}

\subsubsection{Ruminants}

In sheep flocks, toxoplasmosis is a major cause of abortion (Buxton, 1990), and consequently economic losses. Certainly, environmental contamination with Toxoplasma oocysts from cat 
feces is a major source of risk from infection at these farm animals (Buxton et al., 2007). In this context, it is important to note that domestic cats are kept on farms to control presence of rodents in the local feed store. Ingestion of infected aborted foetuses and placentas, and rodents infected birds can lead to the excretion of large amounts of oocysts environment (Zedda et al., 2009). These oocysts are very resistant to environmental conditions. They survive short periods of cold and dehydration, and to remain infectious in moist soil or sand up to 18 months. Moreover, they are highly waterproof and resistant to disinfectants (Tenter et al., 2000).

Although the prevailing view of sheep infected with T. gondii is this happens after birth, some studies have suggested that in exceptional circumstances, vertical transmission can occur with greater frequency (Buxton et al., 2006; Rodger et al., 2006). On the other hand, other researchers have suggested that infection via placenta is not that unusual, obtaining high rates of congenital transmission (Duncanson et al., 2001; Morley et al., 2005; Morley et al., 2008). However, there is a severe criticism concerning these recent studies, since authors conclusions were based only on PCR results, no other agents that cause abortions in sheep flocks involved in the studies (Dubey, 2009a).

The cattle is not considered an important reservoir of T. gondii (Dubet et al., 2009b), and offer no major risks for transmission of the agent to humans (Kijlstra \& Jongert, 2008). On the other hand, has been suggested possible sexual transmission of the parasite among cattle, due to the presence $T$. gondii oocysts and in the forms of thachyzoites in semen samples (Scarpelli et al., 2009). Another interesting question is related to risk factors infection to cattle, since, if the increase in the number of cats on a farm increases possibility infection, presence of chickens is considered protective factor. The protection is provided by chicken presence probable due to the chickweed and other forage plants, seeds, and insects that partially clean environment from contaminating oocysts (Albuquerque et al., 2011).

\subsection{Congenital toxoplasmosis in woman}

Congenital toxoplasmosis can cause fetal abnormalities, abortion, stillbirth, and can interfere with the quality of life of children who survived the prenatal infection (Tenter et al., 2000). This form of infection is the consequence of a primary contact with the parasite during pregnancy (Cenci-Goga et al., 2011). However, the severity of congenital toxoplasmosis and the risk of intrauterine infection are closely related to the immunocompetence of the mother during parasitemia, the number and virulence of parasites transmitted to the fetus, as well as the age of the fetus at the time of transmission (Tenter et al., 2000). The damage generated in the fetus are more pronounced when they are infected in early pregnancy. Retinochoroiditis, hydrocephalus, microcephaly, and calcification are among the largest endocranial injuries (Goldenberg \& Thompson, 2003). However, if fetal infection occurs in the final third pregnancy, damage to the fetus are smaller, asymptomatic newborns (Tenter et al., 2000).

However, if fetal infection occurs in the final third of pregnancy, damage to the fetus are smaller, asymptomatic newborns (Tenter et al., 2000). Pregnant immunocompromised, especially those infected with HIV, are more likely to reactivation of retinochoroiditis (Vogel et al., 1996), and the risk of fetal involvement varies between 2 and 5\% (Remington et al., 2006). However, it is not ruled out the possibility of congenital toxoplasmosis in an 
immunocompetent mother with reactivation of chronic infection Tues eye disease during pregnancy (Andrade et al., 2010).

Serological screening in prenatal and epidemiological surveillance can be critical to reducing the risk of congenital toxoplasmosis (Mioranza et al., 2008). In regions with low prevalence of the disease, this may be an alternative strategy. However, in regions of high prevalence, these two factors are essential. Pregnant women who present with a suspected infection with $T$. gondii acquired during pregnancy should be immediately treated with spiramycin (Thiébaut et al., 2007). If the fetal T. gondii infection is confirmed, or in infections acquired in the later stages of pregnancy (when the rate of maternal-fetal transmission is highest), the specific treatment of the mother with pyrimethamine, sulfadiazine and folinic acid should be considered (Montoya et al., 2008). Still, there are still uncertainties related to the effectiveness of treatment of congenital toxoplasmosis. In a meta-analysis study of 2007, researchers found weak evidence for association between early treatment and reduced risk of congenital toxoplasmosis. In 550 liveborn infants infected identified by prenatal or neonatal screening, no evidence that prenatal treatment significantly reduced the risk of clinical manifestations was found (Thiébaut et al., 2007).

\subsection{Vaccination against $T$. gondii}

Veterinary vaccines against toxoplasmosis may have different purposes, such as the prevention of congenital toxoplasmosis, reduction of tissue cysts or vaccines to reduction oocyst shedding (Innes et al., 2007). There is a vaccine against T. gondii licensed for veterinary use in sheep and goats. The vaccine consists of living and a modified strain of the parasite (S48), and commercially known as Toxovax ${ }^{\circledR}$, suitable for prevention of congenital toxoplasmosis in these ruminants. It is recommended to apply the vaccine three weeks before mating and it is estimated that the application of this immunobiological $2 \mathrm{~mL}$ subcutaneously induces protective immunity for at least 18 months (Dubey, 2009). However, this vaccine is not indicated for use in women because it is a parasite living in their composition. It is important that killed vaccines with high immunogenic power are able to stimulate an immune response strong and durable, providing good security for use in women and, thus, preventing congenital infection (Innes, 2010).

From the standpoint public health a vaccine to prevent shedding oocysts by cats is a great alternative (Cenci-Goga et al., 2011) in order to avoid contamination of environments. Nevertheless, as T. gondii does not cause clinical disease in cats, the private sector shows no interest in developing an immunobiological for this purpose, even though use a vaccine composed of a mutant strain of T-263 bradyzoites, able to avoid shedding oocysts per cats, has succeeded in reducing exposure the parasite of pigs (Mateus-Pinilla et al., 1999). Just as financial support toward the development of vaccines for neglected diseases such as visceral leishmaniasis and malaria comes from public agencies, the incentive to produce a vaccine for cats that would come from public health agency and cat owners have to be persuaded to purchase and use the vaccine for the public good (Innes, 2010).

\section{Perception farmers in control and prevention abortive zoonosis in herds}

\subsection{Aspects in livestock}

Production agriculture is associated with a variety of occupational illnesses and injuries. Agricultural workers are at higher risk of death or disabling injury than most other workers. 
Traumatic injury commonly occurs from working with machinery or animals. Respiratory illness and health problems from exposures to farm chemicals are major concerns, and dermatosis, hearing loss, certain cancers, and zoonotic infections are important problems (Von Essen \& McCurdy, 1998). In relation to animal production, the current situation of dairy farming, which also coincides with trends observed in other agricultural activities, is reducing the number of units production (dairy cows) and increased productivity (volume of milk per lactation) (Hayirli et al., 2002). However, productivity growth has been associated with increased incidence of diseases that can lead to economic losses for the producer, the greatest risk of antibiotic residues in milk, as well as increased frequency of antimicrobial resistant microorganisms isolated from the milk of dairy herds (Bal et al., 2010; Call et al., 2008; Nam et al., 2010), and negative perception of the population by the dairy industry (Grummer, 1995). In this context, an animal health program should consist veterinary activities in planning regularly applied and good management to maintain the herd health animal and productivity at optimum levels.

The profitability of any livestock production system basically depends on production efficiency, product quality, and especially reproductive efficiency, since the raw material needed to carry out productive characteristics is dependent on the reproductive process and the animal health status a herd. Infectious diseases, bacterial, viral or parasitic origin are important in this context, since they affect the reproductive system of males and females, preventing fertilization, causing abortions, repetition of heat, and the birth of animals with below average size. In addition, many of these organisms have zoonotic, such as bacteria and protozoa discussed in this chapter. Thus, the preventive control of males and females is crucial to get as many animals healthy at birth and hence more profitable production system (Viana \& Zanini, 2009b).

Currently, the increasingly globalized world, is no longer possible to treat individual countries as the requirements for marketing for both domestic consumption and for import and export of food is becoming increasingly stringent, homogeneous, the norms established by the bodies international. Any country which has a large potential to double its food production, increasing its share in the international market of products of animal origin, should urgently develop a Strategic Security Program Food (SSPF). These measures are correlated with trends in the global market. Today there is greater concern in producing good quality products with social responsibility. In this sense, is charged to the farmer greater commitment on the quality of products, processes, and animal welfare as well as environmental responsibility and human resource availability (Jakobsen \& Kristensen, 2011a). Moreover, in recent decades there has been a drastic change on the view that prevention could bring more satisfactory results rather than curative treatment. Furthermore, studies in veterinary medicine sought to identify and limit reproductive disorders at an early stage. In this sense, the concept of prevention of zoonotic diseases in livestock can be raised through an analysis of environmental or ecosystems health, linking cattle and people (LeBlanc et al., 2006).

\subsection{Farmers and health education}

\subsubsection{Inside farm}

The lack of knowledge and awareness of farmers on the importance of prevention and control of zoonosis in the farm, is not limited to developing countries. The same problem 
related to health education has been observed in developed countries. The decisions taken by farmers in the farm can generate great impact on society, especially in public health (Ellis-Iversen et al., 2010). Unlike the European Union (EU) that has a law that transferred responsibility to the farmers to implement animal disease control programs within the farm EU Zoonosis Directive (EC) No. 2003/99 and the Zoonosis Regulation (EC) No. 2160/2003, in many countries there are not well-established plans, mainly in South America, Africa and Asia. However, even in European countries, the attempt to implement the hazard analysis critical control points (HACCP), so that guide to good hygiene practices is adopted on farms, it is not feasible (Cavirani, 2008).

Surveys have shown that smallholder, although knowing that zoonotic agents can be transmitted through milk, do not you name them, and lacking basic information about the spread of pathogens in a herd. However, brucellosis is usually the most remembered among the zoonosis that cause reproductive disorders. This is due in part to the economic losses generated by Brucella abortus due to reproductive failure. Moreover, in many countries established compulsory vaccination against this disease (John et al. 2008; Mosalagae et al., 2011, Viana \& Zanini, 2009a).

Another important issue is related biosecurity, which provides for the adoption of a set of measures and their benefits have been proven not only to achieve eradication, but also to keep the property free of disease infectious diseases in animal populations. A recent study showed that to implement biosecurity measures on farms, it is necessary motivation for farmers, since results are more likely to benefit society than individual farmer. However, farmers and policy-makers are faced with important questions about biosecurity at farmlevel related to the sanctioning system within the contextual framework of social dilemmas. Therefore, the authors proposed the development of a market-mediated system to (1) reduce the risk of free-riders, and (2) provide farmers with incentives to improve biosecurity at farm-level (Kristensen \& Jakobsen, 2011). Researchers of South-East Asia suggest that in lieu of a widespread public awareness program to deliver mass education of smallholder in disease prevention and biosecurity, livestock development projects in region, should be encouraged to include training in disease risk management as an important intervention if the current momentum for trade in large ruminant livestock and large ruminant meat is to continue to progress and contribute to addressing global food security concerns (Nampanya et al., 2011). Another study conducted in Sweden, 50\% of livestock farmers living in herds with no previous isolation (Noremark et al., 2010). This decision making is crucial in the dissemination of zoonotic pathogens into a herd.

\subsubsection{Attention to vaccination and veterinarian as advisor}

Vaccination against infectious abortion can be an effective part in a program of animal health and biosecurity. However, although this practice capable of generating results broadly favorable, due to increased herd immunity and reduce the impact of an outbreak, vaccination alone is not able to prevent zoonotic infections and loss (Sanderson \& Gnade, 2002). In the practical context of vaccination livestock, it is important to highlight a sensitive issue: smallholders in regions most in need of infrastructure and government support have greater difficulties in joining such practices. Farmers have limited resources more difficult to observe the benefits of vaccination a herd with no imminent risk of certain disease (Rogers, 2003). On the other hand, an important study developed with poor farmers in Bolivia, 
revealed that, contrary to recent literature, the behavior of livestock vaccination is strongly linked to social and cultural characteristics, rather than economic. Furthermore, uptake of livestock vaccination was unlikely to improve without knowledge transfer that acknowledges local epistemologies for livestock disease (Heffernan et al., 2008).

The veterinarian is an important tool management process. However, to exercise its role of advisor, you need confidence to the farmers. Is a suggested veterinarian undergo training on communication and reflection. For the farmer recognizes his work as trusted advisor in order to herd health, the veterinarian must go through a personal learning (Kristensen \& Jakobsen, 2011b). The veterinarian's role in this matter may go further. Under study developed Ohio, 92 physicians were interviewed about self-assessment of knowledge of zoonosis. The survey demonstrated that over $50 \%$ of physicians were either mostly uncomfortable or strongly uncomfortable with their knowledge of zoonosis, and in their ability to diagnose and make recommendations on how to prevent zoonotic infections. Furthermore, fifty-three percent felt a collaborative relationship with a veterinarian who possessed specialty training in zoonosis would be valuable to their practice. A gap may exist in the delivery of zoonosis information and patient care, requiring better communication between health care providers, veterinarians, and public health officials serving farmers (Kersting et al., 2009).

\section{Conclusion}

The issues addressed in this chapter on zoonotic agents responsible for reproductive disorders in herds, extend beyond the economic losses generated by consequent loss of production (milk and meat) and reproductive (abortion, stillbirth, repetition of heat). Much has been emphasized on the generation of livestock products of excellent quality, free of virulent zoonotic pathogens, and this is not a recent warning. Unfortunately, no easy task control infections discussed in this work, especially in countries located below the Equator, as previously discussed. Recent studies have demonstrated how unprepared the farmer with simple sanitary and health education, either by socioeconomic and / or cultural. In this regard, the authors recommend the approach between three factors: (1) Universities, (2) society and (3) political authorities in generation knowledge and awareness of workers from rural areas about the importance of their work public health. The practice of extension becomes a great teaching resource, and associated with a language accessible to farmers, can be very effective, and generate human resources. In this context comes the veterinarian as a key element in mediation. Nevertheless, it is essential commitment of public health policy, is well established in the design of surveillance programs, control and eradication of certain zoonosis, is in direct support to farmers. That is, without mutual collaboration these three factors is practically impossible to obtain satisfactory results after a specific zoonosis.

\section{References}

Acha, P. N. \& Szyfres, B. (2003). Zoonosis y enfermedades transmisibles comunes al hombre y a los animales, Organización Panamericana de la Salud/Oficina Sanitária Panamericana, ISBN 92-75-31991-X, 3th ed. Washington

Ajioka, J. W.; Fitzpatrick, J. M. \& Reitter, C. P. (2001). Toxoplasma gondii genomics: shedding light on pathogenesis and chemotherapy. Expert Review Molecular Medicine, Vol.6, No.1, (January 2001), pp. 1-19, ISSN 1462-3994 
Albuquerque, G. E.; Munhoz, A. D.; Teixeira, M.; Flausino, W.; Medeiros, S. M. \& Lopes, C. W. G. (2011). Risk factors associated with Toxoplasma gondii infection in dairy cattle, State of Rio de Janeiro. Pesquisa Veterinária Brasileira, Vol.31, No.4, (Abril 2011), pp. 287-290, ISSN 0100-736X

Almuneef, M. A.; Memish, Z. A.; Balkhy, H. H,; Alotaibi, B.; Algoda, S.;Abbas, M. \& Alsubaie, S. (2004). Importance of screening household members of acute brucellosis cases in endemic areas. Epidemiology and Infectious. Vol.132, No.3, (June 2004), pp. 533-540, ISSN 0950-2688

Alves, T. M., Stynem, A. P. R.; Miranda, K. L. \& Lage, A. P. (2011). Campilobacteriose genital bovina e tricomonose genital bovina: epidemiologia, diagnóstico e controle. Pesquisa veterinária Brasileira, Vol.31, No.4, (Abril 2011), pp. 336-344, ISSN 1678-5150

Andrade, G. M. Q.; Vasconcelos-Santos, D. V.; Carellos, E. V. M.; Romanelli, R. M. C.; Vitor, R. W. A.; Carneiro, A. C. A. V. \& Januario, J. N. (2010). Congenital toxoplasmosis from a chronically infected woman with reactivation of retinochoroiditis during pregnancy. Jornal de Pediatriai, Vol.86, No.1, (January 2010), pp. 85-88, ISSN 00217557

Angelakis, E. \& Raoult, D. (2010). Q fever. Veterinary microbiology, Vol.140, No.4, (January 2010), pp. 297-309, ISSN 0378-1135

Arricau-Bouvery, N. \& Rodolakis, A. (2005). Is Q fever an emerging or reemerging zoonosis? Veterinary Research, Vol.36, No.3, (June 2005), pp. 327-349, ISSN 1297-9716

Bal, E. B. B.; Bayar, S. \& Bal, M. A. (2010). Antimicrobial susceptibilities of CoagulaseNegative Staphylococci (CNS) and Streptococcifrom bovine subclinical mastitis cases. The Journal of Microbiologyi, Vol.48, No.3, (June 2010), pp. 267-274, ISSN 1976-3794

Blasco, J. M. \& Moryon, I. (2010) Eradication of bovine brucellosis in the Azores, PortugalOutcome of a 5-year programme (2002-2007) based on test-and-slaughter and RB51 vaccination. Preventive Veterinary Medicine, Vol.94, No.2, (April 2010), pp. 154-157, ISSN 0167-5877

BonDurant, R. H. (2005). Venereal diseases of cattle: natural history, diagnosis, and the role of vaccines in their control. Veterinary Clinics of North America: Food Animal Practice, Vol.21, No.2, (July 2005), pp. 383-408, ISSN 0749-0720

Butzler, J. P. (2004). Campylobacter, from obscurity to celebrity. Clinical Microbiology and Infection, Vol.10, No.10, (October 2004), pp. 868-876, ISSN 1198743X

Buxton, D. (1990). Ovine toxoplasmosis: a review. Journal of the Royal Society of Medicine, Vol.83, No.8, (August 1990), pp. 509-511, ISSN 1758-1095

Buxton, D.; Rodger, S. M.; Maley, S. W. \& Wright, S. E. (2006). Toxoplasmosis: the possibility of vertical transmission. Small Ruminant Research, Vol.62, No.2, (March 2006), pp. 43-46, ISSN 0921-4488

Buxton, D.; Maley, S. W.; Wright, S. E.; Rodger, S.; Bartley, P. \& Innes, E. A. (2007). Toxoplasma gondii and ovine toxoplasmosis: New aspects of an old story. Veterinary Parasitology, Vol.149, No.2, (October 2007), pp. 25-28, ISSN 0304-4017

Call, D. R.; Davis, M. A. \& Sawant, A. A. (2008). Antimicrobial resistence in Beef and dairy cattle production. Animal Health Research Reviews, Vol.9, No.2, (December 2008), pp. 159-167, ISSN 1475-2654

Cantas, H.; Muwonge, A.; Sareyyupoglu, BYardimci, H. \& Skjerve, E. (2011). Q fever abortions in ruminants and associated on-farm risk factors in northern Cyprus. Veterinary Research, vol.17, No.1, (March 2011), pp. 7-13, ISSN 1746-6148 
Carcopino, X.; Raoult, D.; Bretelle, F.; Boubli, L. \& Stein, A. (2009). Q fever during pregnancy A cause of poor fetal and maternal outcome. Annals of The New York Academy of Sciences, Vol.1166, No.1, (May 2009), pp. 79-89, ISSN 0077-8923

Cavirani, S. (2008). Cattle industry and zoonotic risk. Veterinary Research Communications, Vol.32, No.1, (August 2008), pp. 19-24, ISSN 1573-7446

Cenci-Goga, B. T.; Rossitto, P. V.; Sechi, P.; McCrindle, C. M. E. \& Cuççor, J. S. (2011). Toxoplasma in animals, food, and humans: an old parasite of new concern. Foodborne Pathogens and Disease, Vol.8, No.7, (July 2011), pp. 751-762, ISSN 15567125

Cerar, D.; Karner, P.; Avsic-Zupanc, T. \& Strle, F. (2009). Azithromycin for acute Q fever in pregnancy. Wiener Klinische Wochenschrift, Vol.121, No.14, (July 2009), pp. 469-472, ISSN 1563-248X

Chang, C. C.; Lin, P. S.; Hou, M. Y.; Lin, C. C.; Hung, M. N.; Wu, T. M.; Shu, P. Y.; Shih, W. Y.; Lin, J. H. Y.; Chen, W. C.; Wu, H. S. \& Lin, L. J. (2010). Identification of risk factors of Coxiella burnetii ( $Q$ fever) infection in veterinary-associated populations in Southern Taiwan. Zoonoses and Public health, Vol.57, No.8, (December 2010), pp. 95101, ISSN 1863-2378

Cobo, E. R.; Cipolla, A.; Morsella, C.; Cano, D. \& Campero, C. (2004). Immunization in heifers with dual vaccines containing Tritrichomonas foetus and Campylobacter fetus antigens using systemic and mucosal routes. Theriogenology, Vol.62, No.8, (November 2004), pp. 1367-1382, ISSN 0093-601X

Cobo, E. R.; Cipolla, A.; Morsella, C.; Cano, D. \& Campero, C. (2003). Effect of two commercial vaccines to Campylobacter fetus subspecies on heifers naturally challenged. Journal of Veterinary Medicine, Vol.50, No.2, (March 2003), pp. 75-80, ISSN 0931-1793

Corbel, M. J. (1997). Brucellosis: an overview. Emergengy Infectious Diseases, Vol.3, No.2, (June 1997), pp. 213-221, ISSN 1080-6059

Cutler, S. J. ; Bouzid, M. \& Cutler, R. R. (2007). Q fever. Journal of Infection, Vol.54, No.4, (April 2007), pp. 313-318, ISSN 0163-4453

Del fava, C.; Arcaro, J. R. P.; Pozzi, C. R.; Arcaro Junior, H.; Fagundes, E. M.; Pituco, E.; De Stefano, L. H.; Okuda, S. \& Vasconcellos, A. (2003). Manejo sanitário para o controle de doenças da reprodução em um sistema leiteiro de produção semiintensivo. Arquivos do Instituto Biológico, Vol.70, No.1, (Março 2003), pp.25-33, ISSN 0020-3653

Dubey, J. P.; Linday, D. S. \& Speer, C. A. (1998). Structures of Toxoplasma gondii Tachyzoites, Bradyzoites, and Sporozoites and biology and Development of Tssue Cysts. Clinical Microbiology Reviews, Vol.11, No.2, (April 1998), pp. 267-299, ISSN 0893-8512

Dubey, J. P. (2009a). Toxoplasmosis in sheep - The last 20 years. Veterinary Parasitology, Vol.163, No.2, (July 2009), pp.1-14, ISSN 0304-4017

Dubey, J. P. (November 2009b). Toxoplasmosis in Animals and Humans (2th Edition), USDA/ARS, ISBN 9781420092363, Maryland, USA

Duncanson, P.; Terry, R. S.; Smith, J. E. \& Hide, G. (2001). High levels of congenital transmission of Toxoplasma gondii in a commercial sheep flock. International Journal for Parasitology, Vol.31, No.14, (December 2001), pp. 1699-1703, ISSN 0020-7519

Ellis-Iversen, J.; Cook, A. J. C.; Watson, E.; Nielen, M.; Larkin, L.; Wooldridge, M. \& Hogeveen, H. (2010). Perceptions, circumstances and motivators that influence 
implementation of zoonotic control programs on cattle farms. Preventive Veterinary Medicinei, Vol.93, No.4, (March 2010), pp. 276-285, ISSN 0167-5877

Franco, M. P.; Mulder, M.; Gilman, R. \& Smits, H. L. (2007) Human brucellosis. The Lancet Infectious Diseases, Vol.7, No.12, (December 2007), pp. 775-786, ISSN 1473-3099

Freitas, J. A. \& Oliveira, J. P. (2005). Pesquisa de infecção brucélica em bovídeos abatidos portadores de bursite. Arquivos do Instituto Biológico, Vol.72, No.4, (December 2005), pp. 427-433, ISSN 1808-1657

Friedman, C. R.;Hoekstra, R. M.; Samuel, M.; Marcus, R.; Bender, J.; Shiferaw, B.; Reddy, S.; Ahuja, S. D.; Helfrick, D. L.; Hardnett, F.; Carter, M.;Anderson, B. \& Tauxe, R. V. (2004). Risk factors for sporadic Campylobacter infection in the United States: a casecontrol study in FoodNet sites. Clinical Infectious Diseases, Vol.38, No.3, (April 2004), pp. 285-296, ISSN 1537-6591

Gilpin, B. J.; Scholes, P.; Robson, B. \& Savill, M. G. (2008). The transmission of thermotolerant Campylobacter spp. to people livingor working on dairy farms in New Zeland. Zoonoses and Public Health, Vol.55, No.7, (September 2008), pp. 352360, ISSN 1863-2378

Goldenberg, R. L. \& Thompson, C. (2003). The infectious origins of stillbirth. American Journal of Obstetrical \& Gynecology, Vol.189, No.3, (September 2003), pp. 861-873, ISSN 0002-9378

Gorvel, P. J. \& Moreno, E. (2002). Brucella intracellular life: from invasion to intracellular replication. Veterinary Microbiology, Vol.90, No.4, (December 2002), pp. 281-297, ISSN 0378-1135

Grummer, R. R. (1995). Impact of changes in organic nutrient metabolism on feeding the transition dairy cow. Journal of Animal Science, Vol.73, No.9, (September 1995), pp. 2820-2833, ISSN 1525-3163

Guatteo, R.; Seegers, H.; Taurel, A. F.; Joly, A. \& Beaudeau, F. (2011). Prevalence of Coxiella burnetii in domestic ruminants: A critical review. Veterinary Microbiology, Vol.149, No.2, (April 2011), pp. 1-16, ISSN 0378-1135

Gul, S. T. \& Khan, A. (2007). Epidemiology and epizootology of brucellosis: a review. Pakistan Veterinary Journal, Vol. 27, No.3, (September 2007), pp. 145-151, ISSN 02538318

Gulsun, S.; Aslan, S.; Satici, O. \& Gul, T. (2011). Brucellosis in pregnancy. Tropical Doctor, Vol.41, No.2, (April 2011), pp. 82-84, ISSN 1758-1133

Gwida, M.; Al Dahouk, S.; Melzer, F.; Rosler, U.; Neubauer, H. \& Tomaso, H. (2010). Brucellosis - Regionally Emerging Zoonotic Disease? Croatian medical Journal, Vol.51, No.4, (December 2010), pp. 289-295, ISSN 1332-8166

Hannon, S. J.; Allan, B.; Waldner, C.; Rusell, M. L.; Potter, A.; Babiuk, L. A. \& Townsend, H. G. (2009). Prevalence and risk factor investigation of Campylobacter species in beef cattle faces from seven large commercial feedlots in Alberta, Canada. Canadian Journal of Veterinary Research, Vol.73, No.4, (October 2009), pp. 275-282, ISSN 08309000

Hayirli, A.; Grummer, R. R.; Nordheim, E. V. Crump, P. M. (2002). Animal and dietary factors affecting feed intake during the prefresh transition period in Holsteins. Journal Dairy Science, Vol.85, No.12, (December 2002), pp. 3430-3443, ISSN 15253198 
Heffernan, C.; Thomson, K. \& Nielsen, L. (2008). Livestock vaccine adoption among poor farmers in Bolivia: Remembering innovation diffusion theory. Vaccine, Vol.26, No.19, (May 2008), pp. 2433-2442, ISSN 0264-410X

Hegazy, Y. M.; Ridler, A. L. \& Guitian, F. J. (2009). Assessment and simulation of the implementation of brucellosis control programme in an endemic area of the Middle East. Epidemiology and Infection, Vol.137, No.10, (October 2009), pp. 1436-1448, ISSN 1469-4409

Hegazy, Y. M.; Molina-Flores, B.; Shafik, H.; Ridler, A. L. \& Guitian, F. J. (2011). Ruminant brucellosis in Upper Egypt (2005-2008). Preventive Veterinary Medicine, Vol.101, No.4, (September 2011), pp. 173-181, ISSN 0167-5877

Huang, J. L.; Xu, H. I.; Bao, G. Y.; Zhou, X. H.; Ji, D. J.; Zhang, G.; Liu, P. H.; Jiang, F.; Pan, Z. M.; Liu, X. F. \&Jiao, X. A. (2009). Epidemiological surveillance of Campylobacter jejuni in chicken, dairy cattle and diarrhoea patients. Epidemiology and Infection, Vol.137, No.8, (August 2009), pp. 1111-1120, ISSN 1469-4409

Hughes, R. A. \& Rees, J. H. (1997). Clinical and epidemiologic features of Guillain-Barré syndrome. The Journal of Infectious Diseases, Vol.176, No.2, (December 1997), pp. $92-$ 98, ISSN 0022-1899

Innes, E. A.; Bartley, P. M.; Maley, S.; Katzer, F. \& Buxton, D. (2009). Veterinary vaccines against Toxoplasma gondii. Memórias do Instituto Oswaldo Cruz, Vol.104, No.2, (March 2009), pp. 246-251, ISSN 0074-0276

Innes, E. A. (2010). Vaccination against Toxoplasma gondii: as increasing priority for collaborative research? Expert Review Vaccines, Vol.9, No.10, (October 2010), pp.1117-1119, ISSN 1476-0584

Jesus, V. L. T.; Trés, J. E.; Jacob, J. C. F.; Latorre, L. B. L. M. \& Santos Junior, J. C. B. (1999). Campilobacteriose genital bovina: ocorrência nos estados do Rio de janeiro e Minas Gerais. Revista Brasileira de medicina Veterinária, Vol.6. No.3, (Dezembro 1999), pp. 133-136, ISSN 1412-0130

John, K.; Kazwala, R. \& Mfinanga, G. S. (2008). Knowledge of causes, clinical features and diagnosis of common zoonoses among medical practitioners in Tanzania. BMC Infectious Diseases, Vol.8, No.4, (December 2008), pp. 162-170, ISSN 1471-2334

Jones, R. M.; Nicas, M.; Hubbard, A. E. \& Reingold, A. L. (2006). The infectious dose of Coxiella burnetii (Q fever). Applied Biosafety, Vol.11, No.1, (March 2006), pp. 32-41, ISSN 1535-6760

Karcaaltincaba, D.; Sencan, I.; Kandemir, O.; Guvendag-Guven, E. S. \& Yalvac, S. (2010). Does brucellosis in human pregnancy increase abortion rosk? Presentation of two cases and review os literature. Journal of Obstetries and Ginaecology Research, Vol.36, No.2, (April 2010), pp. 418-423, ISSN 1447-0756

Kersting, A. L.; Medeiros, L. C. \& LeJeune, J. T. (2009). Zoonoses and the physicians role in educating farming patients. Journal of Agromedicine, Vol.14, No.3, (August 2009), pp. 306-311, ISSN 1059-924X

Khan, M. Y.; Mah, M. W. \& Memish, Z. A. (2001). Brucellosis in pregnant women. Clinical infectious Diseases, Vol.32, No.8, (April 2001), pp. 1172-1177, ISSN 1537-6591

Kijlstra, A. \& Jongert, E. (2008). Control os the risk of human toxoplasmosis transmitted by meat. International Journal for parasitology, Vol.38, No.12, (October 2008), pp. 13591370, ISSN 0020-7519 
Kolar, J. Diagnosis and control of brucellosis in small ruminants. Preventive Veterinary Medicine, Vol.2, No.4, (March 1984), pp. 215-225, ISSN 0167-5877

Kristensen, E. \& Jakobsen, E. B. (2011). Danish dairy farmers perception of biosecurity. Preventive Veterinary Medicine, Vol.99, No.4, (May 2011), pp. 122-129, ISSN 01675877

Kristensen, E. \& Jakobsen, E. B. (2011). Challenging the myth of the irrational dairy farmer; understanding decision-making related to herd health. New Zealand Veterinary Journal, Vol.59, No.1, (July 2011), pp. 1-7, ISSN 1176-0710

Kuwabara, S.; Oqawara, K.; Misawa, S.; Koqa, M.; Mori, M. Hiraqa, A.; Kanesaka.; Hattori, T. \& Yuki, N. (2004). Does Campylobacter jejuni infection elicit demyelinating Guallain-Barre syndrome?. Neurology, Vol.63. No.3, (August 2004), pp. 529-533, ISSN 0028-3878

Lago, E. G.; Carvalho, R. L.; Jungblut, R.; Da Silva, V. B. \& Fiori, R. M. (2009). Screening for Toxoplasma gondii antibodies in 2,513 consecutive parturient women and evaluation of newborn infants at risk for congenital toxoplasmosis. Scientia Medica, Vol.9, No.1, (March 2009), pp. 27-34, ISSN 1980-6108

LeBlanc, S. J.; Lissemore, K. D.; Kelton, D. F.; Duffield, T. F. \& Leslie, K. E. (2006). Major advances in disease prevention in dairy cattle. Journal Dairy Science, Vol.89, No.4, (April 2006), pp. 1267-1279, ISSN 1525-3198

Leite, R. C. (1977). Avaliação de alguns métodos de diagnóstico e análise custo/benefício do controle da campilobacteriose bovina. Dissertação de Mestrado em Medicina Veterinária Preventiva, Escola de Veterinária, Universidade Federal de Minas Gerais, Belo Horizonte, MG. 38p

Leonard, E. E.; Tompkins, L. S.; Falkow, S. \& Nachamkin, I. (2004). Comparison of Campylobacter jejuni isolates implicated in Guillain-Barre syndrome and strains that cause enteritis by a DNA microarray. Infection and Immunity, Vol.72, No.2, (February 2004), pp. 1199-1203, ISSN 1098-5522

Ling, V. J.; Lester, D.; Mortensen, P. B.; Langenberg, P. W. \& Postolache, T. T. (2011). Toxoplasma gondii seropositivity and suicide rates in women. The Journals of Nervous and mental Disease, Vol.199, No.7, (July 2011), pp. 440-444, ISSN 1539-736X

Lucero, N. E.; Ayala, S. M.; Escobar, G. I. \& Jacob, N. R. (2008). Brucella isolated in humans and animals in Latin America From 1968 to 2006. Epidemiology and Infection, Vol.136, No.4, (April 2008), pp. 496-503, ISSN 1469-4409

Makita, K.; Fevre, E. M.; Waiswa, C.; Kaboyo, W.; Del Clare Bronsvoort, B. M. \& Welburn, S. C. (2008). Human brucellosis in urban and peri-urban areas of kampala, Uganda. Annals of the New york Academy of Sciences, Vol.1149, (December 2008), pp. 309-311, ISSN 1749-6632

Marrie, T. J.; Schlech, W. F.; Williams, J. C. \& Yates, L. (1986). Q fever pneumonia associated with exposure to wild rabbits. The lancet, Vol.22. No.1, (February 1986), pp. 427-429, ISSN 0140-6736

Maurin, M. \& Raoult, D. (1999). Q fever. Clinicam Microbiology Reviews, Vol.12, No.4, (October 1999), pp. 518-552, ISSN 1098-6618

Mediannikov, O.; Fenolar, F.;Socolovschi, C.; Diatta, G.; Bassene, H.; Molez, J. F.; Sokhana, C.; Trape, J. F. \& Raoult, D. (2010). Coxiella burnetii in humans and ticks in rural Senegal. Plos Neglected Tropical Disease, Vol.4, No.4, (April 2010), pp. e654, ISSN 1935-2735 
Merianos, A. (2007). Surveillance and responde to disease emergence. Current Topics in Microbiology and Immunology, Vol.315, pp. 477-509, ISSN 0070-217X

Mioranza, S. L.; Meireles, L. R.; Mioranza, E. L. \& Andrade Júnior, H. F. (2008). Evidência sorológica da infecção aguda pelo Toxoplasma gondii em gestantes de Cascavel, Paraná. Revista da Sociedade Brasileira de Medicina Tropical, Vol.41, No.6, (December 2008), pp. 628-634, ISSN 0037-8682

Monno, R.; Fumarola, L.; Trerotoli, P.; Cavone, D.; Giannelli, G.; Rizzo, C.; Cireroni, L. \& Musti, M. (2009). Seroprevalence of $Q$ fever, brucellosis and leptospirosis in farmers and agricultural workers in Bali, Southern italy. Annals of Agricultural and Envoronmental Medicine, Vol.16, No.2, (December 2009), pp. 205-209, ISSN 1232-1966

Montoya, J. G.; Remington, J. S. (2008). Management of Toxoplasma gondii infection during pregnancy. Clinical Infectious Diseases, Vol.47, No.4, (July 2008), pp. 554-66, ISSN $1537-6591$

Moore, J. E.; Corcoran, D.; Dooley, J. S. G.; Fanning, S.; Lucey, B.; Matsuda, M.; MacDowell, D. A.; Mégraud, F.; Cherie Millar, B.; Mahony, R. O.; Riordan, L. O.; Rourke, M. O.; Rao, R. O.; Rooney, P. J.; Sails, A. \& Whyte, P. (2005). Campylobacter. Veterinary research, Vol.36, No.3, (June 2005), pp. 351-382, ISSN 1297-9716

Morley, E. K.; Williams, R. H.; Hughes, J. M.; Terry, R. S.; Duncanson, P.; Smith, J. E. \& Hide, H. (2005). Significant familial differences in the frequency of abortion and Toxoplasma gondii infection within a flock of Charollais. Parasitology, Vol.131, No.2, (August 2005), pp. 181-185, ISSN 0031-1820

Morley, E. K.; Williams, R. H.; Hughes, J. M.; Tomasson, D.; Terry, R. S.; Duncanson, P.; Smith, J. E. \& Hide, H. (2008). Evidence that primary infection of Charollais sheep with Toxoplasma gondii may not prevent foetal infection and abortion in subsequent lambings. Parasitology, Vol.135, No.2, (February 2008), pp. 169-173, ISSN 0031-1820

Mosalagae, D.; Pfukenyi, D. M. \& Matope, G. (2011). Milk producers awareness of milkborne zoonoses in selected smallholder and commercial dairy farms of Zimbabwe. Tropical Animal Health and Production, Vol.43, No.3, (march 2011), pp. 733-739, ISSN 1573-7438

Muskens, J.; van Maanen, C. \& Mars, M. H. (2011). Dairy cows with metritis: Coxiella burnetii test results in uterine, blood and bulk milk samples. Veterinary Microbiology, Vol.147, No.2, (January 2011), pp. 186-189, ISSN 0378-1135

Mshelia, G. D.; Amin, J. D.; Woldehilwet, Z.; Murray, R. D. \& Eqwu, G. O. (2010). Epidemiology and bovine venereal campylovacteriosis: geographic distribuition and recent advances in molecular diagnostic techniques. Reproduction in Domestic Animals, Vol.45, No.5, (October 2010), pp. 221-230, ISSN 0936-6768

Naletoski, I.; Kirandziski, T.; Mitrov, D.; Krstevski, K.; Dzadzovski, I. \& Acevski, S. (2010). Gaps in brucellosis campaing in sheep and goats in Republic of Macedonia: lessons learned. Croatian Medical Journal, Vol. 51, No.4, (August 2010), pp. 351-356, ISSN 1332-8166

Nam, H. M.; Lim, S. K.; Kim, J. M.; Kang, H. M.; Moon, J. S.; Jang, G. C.; Kim, J. M.; Wee, S. H.; Joo, Y. S. \& Jung, S. C. (2010). Antimicrobial susceptibility of coagulase negative Staphylococci isolated from bovine mastitis between 2003 and 2008 in Korea. Journal of Microbiology and Biotechnology, Vol.20, No.10, (July 2010), pp. 1446-1449, ISSN 1738-8872 
Nampanya, S.; Suon, S.; Rast, L. \& Windsor, P. A. (2011). Improvement in smallholder farmer knowledge of cattle production, health and biosecurity in Southern Cambodia between 2008 and 2010. Transboundary and Emerging Disease, Vol.58, No.3, (July 2011), pp. 1-11, ISSN 1865-1682

Noremark, M.; Frossling, J. \& Lewerin, S. S. (2010). Application of routines that contribute to on-farm biosecurity as reported by Swedish livestock farmers. Trandboundary and Emerging Diseases, Vol.57, No.4, (August 2010), pp. 225-236, ISSN 1865-1682

OIE. (August 2011). Bovine genital campylobacteriosis. World Organization for Animal Health,14.08.2011,Availablefromhttp:// web.oie.int/wahis/public.php?page=disea se_status_map\&disease_type=Terrestrial\&disease_id=31\&disease_category_terrest rial=0\&empty=999999\&disease_category_aquatic=0\&disease_serotype=0\&sta_met hod=semesterly\&selected_start_year=2010\&selected_report_period=2\&selected_st art_month $=1 \&$ page $=$ disease_status_map\&date_submit $=\mathrm{OK}$

Pappas, G.; Akritidis, N.; Bosilkovski, M. \& Tsianos, E. (2005). Brucellosis. The New England Journal of Medicine, Vol.352, No.22, (June 2005), pp. 2325-2336, ISSN 0028-4793

Pebody, R. G.; Ryan, M. J. \& Wall, P. G. (1997). Outbreaks of Campylobacter infection: rate events for a common pathogen. Communicable Disease Report CDR Review, Vol.7. No.3, (March 1997), pp. 33-37, ISSN 1350-9349

Psaroulaki, A.; Hadjichristoudoulou, C.; Loukaides, F.; Soteriades, E.; Konstantinidis, A.; papastergiou, P.; ioannidou, M. C. \& Tselentis, Y. (2006). Epidemiological study of $\mathrm{Q}$ fever in humans, ruminant animals, and ticks in Cyprus using a geographical information system. European Journal of Clinical microbiology \& Infectious Diseasesi, Vol.25, No.9, (September 2006), pp. 576-586, ISSN 0934-9723

Remington, J. S.; McLeod, R.; Thulliez, P. \& Desmonts, G. (2006). Toxoplasmosis, In: Infectious Diseases of the Fetus and Newborn Infant, Remington, J. S.; Klein, J. O.; Wilson, C. B. \& Baker, C. J., pp. 947-1091, Elsevier Saunders, ISBN 0721605370, Philadelphia, EUA

Rodger, S. M.; Maley, S. W.; Wright, S. E.; Mackellar, A.; Wesley, F.; Sales, J. \& Buxton, D. (2006). Roleof endogenous transplacental transmission in toxoplasmosis in sheep. Veterinary Record, Vol.159, no.23, (December 2006), pp. 768-772, ISSN 0042-4900

Rogers, E. M. (2003). Diffusion of Innovations. Rogers, E. M, ISBN 0743222091, New York

Rosenthal, B. M. (2009). How has agriculture influenced the geography and genetics of animal parasites? Trends in Parasitology, Vol.25, No.2, (February 2009), pp. 67-70, ISSN 1471-4922

Scarpelli, L.; Lopes, W. D. Z.; Migani, M.; Bresciani, K. D. S. \& Costa, A. J. (2009). Toxoplasma gondii in experimentally infected Bos Taurus and Bos indicus semen and tssues. Pesquisa Veterinária Brasileira, Vol.29, No.1, (January 2009), pp. 59-64, ISSN 0100736X

Sanderson, M. W. \& Gnad, D. P. (2002). Biosecurity for reproductive disease. Veterinary clinics of North America: Food Animal Practice, Vol.18, No.1, (March 2002), pp. 79-98, ISSN 0749-0720

Seleem, M. N.; Boyle, S. M. \& Sriranganathan, N. (2010). Brucellosis: A re-emerging zoonosis. Veterinary Microbiology, Vol.140, No.4, (January 2010), pp. 392-398, ISSN 0378-1135 
Sheldon, I. M.; Lewis, G. S.; LeBlanc, S. \& Gilbert, R. O. (2006). Defining postpartum uterine disease in cattle. Theriogenology, Vol.65, No.8, (May 2006), pp. 1516-1530, ISSN 0093$691 X$

Solera, J. (2000). Treatment of human brucellosis. Journal Medical Libanais, Vol.48, No.4, (August 2000), pp. 255-263, ISSN 0023-9852

Sprong, H.; Tijsse-Klasen, E.; Langelaar, M.; De Bruin, A.; Fonville, M.; Gassner, F.; Takken, W.; Van Wieren, S.; Nijhof, A.; Jongejan, F.; Maassen, c. B.; Scholt, E. J.; Hovius, J. W.; Hemil Hovius, K.; Spiltalská, E. \& van Duynhoven, Y. T. (2011). Prevalence of Coxiella burnetii in ticks after a large outbreak of $\mathrm{Q}$ fever. Zoonoses and Public Health, Vol.58, No.4, (June 2011), pp. 1-7, ISSN 1863-2378

Stynen, A. P. R.; Pellegrin, A. O.; Fóscolo, C. B.; Figueiredo, J. F.; Canela Filho, C.; Leite, R. C. \& Lage, A. P. (2003). Campilobacteriose genital bovina em rebanhos leiteiros com problemas reprodutivos da microrregião de Varginha-Minas Gerais. Arquivo Brasileiro de medicina Veterinária e Zootecnia, Vol.55, No.6, (Dezembro 2003), pp. 766769, ISSN 0102-0935

Tam, C. C.; O`Brien, S. J.; Adak, G. K.; Meakins, S. M. \& Frost, J. A. (2003). Campylobacter coli - an important foodborne pathogen. The Journal of Infection, Vol.47, No.1, (July 2003), pp. 28-32, ISSN 0163-4453

Tatsumi, N.; Baumgartner, A.; Qiao, Y.; Yamamoto, I. \& Yamaguchi, K. (2006). Detection of Coxiella burnetii in market chicken eggs and mayonnaise. Annals of The New York Academy of Sciences, Vol.1078, No.1, (October 2006), pp. 502-505, ISSN 0077-8923

Tenter, A. M.; Heckeroth, A. R. \& Weiss, L. M. (2000). Toxoplasma gondii: from animals to humans. International Journal For Parasitology, Vol.30, No.13, (November 2000), pp.1217-1258, ISSN 0020-7519

Thiébaut, R.; Leproust, S.; Chêne, G. \& Gilbert, R. (2007). Effectiveness of prenatal treatment for congenital toxoplasmosis: a meta-analysis of individual patients' data. Lancet, Vol.369, No.9556, (January 2007), pp. 115-122, ISSN 0140-6736

To, H.; Htwe, K. K.; Kako, N.; Kim, H. J.; Yamaguchi, T.; Fukushi, H. \& Hirai, K. (1998). Prevalence of Coxiella burnetii infection in dairy cattle with reproductive disorders. Journal of veterinary medical science, Vol.60, No.7, (July 1998), pp. 359-361, ISSN 13477439

Van Bergem, M. A.; Linnane, S.; Van Putten, J. P. \& Wagenaar, J. A. (2005). Global detection and identification of Campylivacter fetus subsp. veneralis. Revue Scientifique et Technique, Vol.24, No.3, (December 2005), pp. 1017-1023, ISSN 0253-1933

Verhoeff-Bakken, L.; Jansen, H. A.; Veld, P. H.; Breumer, R. R.; Zwietering, M. H. \& Van Leusden, F. M. (2011). Consumption of raw vegetables and fruits: a risk factor for Campylobacter infections. International Journal of Food Microbiology, Vol.144, No.3, (January 2011), pp. 406-412, ISSN 0168-1605

Viana, K. F.; Moraes, G. C. \& Zanini, M. S. (2009a). Frequency of anti-Brucella abortus antibodies in cattle for Alegre municipality, Espírito Santo State, Brazil. Acta Veterinaria Brasilica, Vol.3, No.1, (March 2009), pp. 13-15, ISSN 1981-5484

Viana, K. F. \& Zanini, M. S. (2009b). Profile of producers faces vaccination against infectious diseases that abortion in cattle municipality Alegre/ES, Brazil. Archives of Veterinary Science, Vol.14, No.2, (June 2009b), pp. 103-108, ISSN 1517-784X

Vogel, N.; Kirisits, M.; Michael, E.; Bach, H.; Hostetter, M.; Bover, K.; Simpson, R.; Holfels, E.; Hopkins, J.; Mach, D.; Mets, M. B.; Swisher, C. N.; Patel, D.; Rolzen, N.; Stein, L.; 
Stein, M.; Withers, S.; Mui, E.; Eqwuaqu, C.; Remington, J.; Dorfman, R. \& McLeod, R. (1996). Congenital toxoplasmosis transmitted from an immunologically competent mother infected before conception. Clinical Infectious Diseases, Vol.23, No.5, (November 1996), pp. 1055-1060, ISSN 1537-6591

Von Essen, S. G. \& McCurdy, S. A. (1998). Health and safety risks in production agriculture. Western Journal of Medicine, Vol.169, No.4, (October 1998), pp. 214-220, ISSN 14762978

Yagmur, F.; Yazar, S.; Temel, H. O. \& Cavusoglo, M. (2010). May Toxoplasma gondii increase suicide attenpt-preliminary results in Turkish subjects? Forensic Science International, Vol.199, No.3, (June 2010), pp. 15-17, ISSN 0379=0738

Young, K. T.; Davis, L. M. \& Dirita, V. J. (2007). Campylobacter jejuni: molecular biology and pathogenesis. Nature Reviews Microbiology, Vol.5, No.9, (September 2007), pp. 665679, ISSN 1740-1526

Zedda, M. T.; Rolesu, S.; Pau, S.; Rosati, I.; Ledda, S.; Satta, G.; Patta, C. \& Masala, G. (2009). Epidemiological study of Toxoplasma gondii infection in ovine breeding. Zoonoses and Public Health, Vol.57, No.2, (January 2009), pp. 102-108, ISSN 1863-2378 


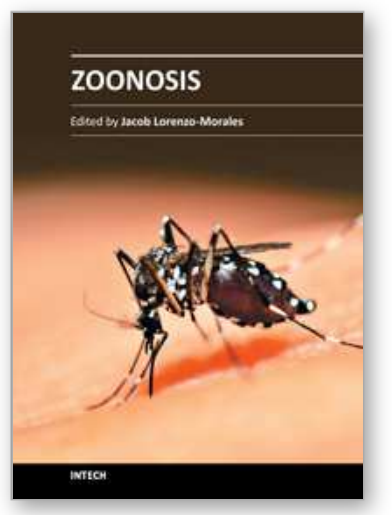

\section{Zoonosis}

Edited by Dr. Jacob Lorenzo-Morales

ISBN 978-953-51-0479-7

Hard cover, 436 pages

Publisher InTech

Published online 04, April, 2012

Published in print edition April, 2012

Zoonotic diseases are mainly caused by bacterial, viral or parasitic agents although "unconventional agents" such as prions could also be involved in causing zoonotic diseases. Many of the zoonotic diseases are a public health concern but also affect the production of food of animal origin thus they could cause problems in international trade of animal-origin goods. A major factor contributing to the emergence of new zoonotic pathogens in human populations is increased contact between humans and animals. This book provides an insight on zoonosis and both authors and the editor hope that the work compiled in it would help to raise awareness and interest in this field. It should also help researchers, clinicians and other readers in their research and clinical usage.

\section{How to reference}

In order to correctly reference this scholarly work, feel free to copy and paste the following:

Kelvinson F. Viana and Marcos S. Zanini (2012). Zoonotic Abortion in Herds: Etiology, Prevention and Control, Zoonosis, Dr. Jacob Lorenzo-Morales (Ed.), ISBN: 978-953-51-0479-7, InTech, Available from: http://www.intechopen.com/books/zoonosis/zoonosis-causing-abortion-in-cattle-and-the-attention-of-farmersin-the-control-and-prophylaxis-

\section{INTECH}

open science | open minds

\section{InTech Europe}

University Campus STeP Ri

Slavka Krautzeka 83/A

51000 Rijeka, Croatia

Phone: +385 (51) 770447

Fax: +385 (51) 686166

www.intechopen.com

\section{InTech China}

Unit 405, Office Block, Hotel Equatorial Shanghai

No.65, Yan An Road (West), Shanghai, 200040, China 中国上海市延安西路65号上海国际贵都大饭店办公楼 405 单元

Phone: +86-21-62489820

Fax: $+86-21-62489821$ 
(C) 2012 The Author(s). Licensee IntechOpen. This is an open access article distributed under the terms of the Creative Commons Attribution 3.0 License, which permits unrestricted use, distribution, and reproduction in any medium, provided the original work is properly cited. 